九州大学学術情報リポジトリ

Kyushu University Institutional Repository

\title{
Morphology and Molecular Characteristics of Pratylenchus japonicus (Ryss, 1988) n. stat. (Nematoda, Pratylenchidae)
}

Mizukubo, Takayuki

Orui, Yukio

Minagawa, Nozomu

https://doi.org/10.5109/2621

出版情報: ESAKIA. 37, pp. 203-214，1997-09-30. Entomological Laboratory，Faculty of Agriculture, Kyushu University バージョン：

権利関係 : 


\title{
Morphology and Molecular Characteristics of Pratylenchus japonicus (Ryss, 1988) n. stat. (Nematoda, Pratylenchidae)
}

\author{
Takayuki MIzukubo \\ Laboratory of Plant Nematology, Kyushu National Agricultural Experiment Station, Nishigoshi, \\ Kumamoto, 86 1- 11 Japan \\ Yukio ORUI \\ Leaf Tobacco Research Laboratory, Japan Tobacco Inc., Oyama, Tochigi, 323 Japan \\ and \\ Nozomu Minagawa \\ Project Research Team 2, National Agricultural Research Center, Tsukuba, Ibaraki. 30.5 Japan
}

\begin{abstract}
Pratylenchus macrostylus japonicus Ryss, 1988 is elevated to the specific rank as P. japonicus, a new status based on the morphological differences observed by an optical and scanning electronic microscope. This species was primarily distinguished from $\mathbf{P}$. macrostylus $\mathrm{Wu}, 1971$ by having shorter spear (18-2 $1 \mu \mathrm{m}$ vs. 21-28 $\mu \mathrm{m})$. Obvious morphological differences are: i) steadily cask-shaped vestibule extension of cephalic frame work in $\mathbf{P}$. japonicus instead of simple widening vestibule extension in $\mathbf{P}$. macrostylus; ii) undivided en face pattern (Group 1) in P. japonicus instead of differentiated median segment (Group 2) in P. macrostylus, iii) much reduced median inner sensilla at the margins of oral aperture in $\mathbf{P}$. japonicus instead of normal sensilla in P. macrostylus, iv) lip region continuous to body contour in $\mathbf{P}$. japonicus instead of offset lip region in $\mathbf{P}$. macrostylus. and v) three lip annuli in $\mathbf{P}$. japonicus instead of two in P. macrostylus. The PCR amplification product, including two ITS regions, a 5.8S gene, and small portions of the $18 \mathrm{~S}$ and $28 \mathrm{~S}$ genes of the rDNA obtained using F194 and F195 primers, was a single fragment of about $800 \mathrm{bp}$. The restriction patterns and the DNA fragment sizes obtained after digestion of 10 endonucleases Alu I, Dde I, Hha I, Hinf I, Taq I, Hae III, Mbo I, Nsp V. Pst I, and Sau 96 I were presented.

Key words: Taxonomy, Nematoda, Pratylenchidae, morphology, molecular characteristics, new status.
\end{abstract}




\section{Introduction}

Pratylenchus macrostylus japonicus Ryss, 1988 is a nematode parasite of trees, such as Quercus spp., Eriobotrya japonica Lindley, and Prunus sp., in Kyushu and Honshu. Japan. The subspecies was recorded three times in Japan as Pratylenchus sp. 1 (Gotoh and Ohshima, 1963), Hoplotylus sp. (Gotoh, 1974), and Pratylenchus macrostylus Wu. 1971 (Minagawa, 1982). Minagawa (1982) gave a detailed description and illustrations of the nematode. An original type of Pratylenchus macrostylus Wu, 197 1, was designated for a Canadian specimen. Though being poorly described, the type specimens were characterized by the conspicuous spear (needle-like apparatus of mouth) of 21-25 $\mu \mathrm{m}$ long; the largest spear among the congeneric species so far known from the world. Because the Japanese populations had a short spear of 17-21 $\mu \mathrm{m}$ long, Ryss ( 1988) transferred the nematode to a subspecific rank of P. macrostylus. Hartman and Eisenback (1991), after the carefully made morphological study of North American populations, suggested again that the Japanese nematode might be closely related to, but different from, North American P. macrostylus, because the spear length, the primary distinguishing feature, was much shorter than that in the types. However, Japanese materials have never been comparatively studied with North American populations nor they are subjected to a scanning electron microscopic (SEM) study for the surface morphology. Therefore, the status of the Japanese nematodes was unclear.

Because the taxonomic characters of nematodes are mostly quantitative morphometrics exhibiting frequent intraspecific variations, recent nematode taxonomy has inclined to use DNA characteristics, especially Internal Transcribed Spacer (ITS) regions of ribosomal DNA (rDNA), to identify species (Zijlstra et al., 1995; Orui, 1996) or to reconstruct phylogeny (Ferris et al., 1993). A combination of the Polymerase Chain Reaction (PCR) amplification of ITS regions of rDNA and a Restricted Fragment Length Polymorphism (RFLP) analysis (PCR-RFLP) was successful to characterize the morphologically recognized Pratylenchus species by species-specific molecular patterns (Orui, 1996).

The objectives of this study are 1) to describe P. macrostylus japonicus in detail with respect to surface morphology and molecular features, and 2) to determine the taxonomic status of the Japanese nematode through designation the required lectotype specimen.

\section{Materials and Methods}

SEM examination. Specimens stored in TAF were processed in $30 \%$ to $100 \%$ ethanol. critical-point dried, coated with platinum-vanadium $(20 \mathrm{~nm})$, and examined in a Hitachi $\mathrm{X}-650 \mathrm{SEM}$ at $10 \mathrm{kV}$.

Preparation of the specimens for measurement and drawing. Observations were made on the specimens killed by gentle heating, fixed in TAF (triethanolamine + formalin: Courtney et al. 1955) and mounted in dehydrated glycerin by the quick method of Seinhorst (1959). The specimens were observed and measured at oil immersion $2.400 \mathrm{x}$ for all features by a Olympus BH-2 light microscope equipped with Normarski interference contrast.

Molecular analysis. An isolate taken from the rhizosphere of cherry tree at Tochigi Prefecture was directly separated from the soil with the Baermann funnel technique. A 
single individual was used for the extraction of template DNA. The DNA was extracted according to Orui (1996). The PCR primer set (F194 and F195 primers) synthesized following Ferris et al. (1993) was used for PCR amplification of the two ITS regions including the $5.8 \mathrm{~S}$ gene and small portions of the $18 \mathrm{~S}$ and $28 \mathrm{~S}$ genes of rDNA. Amplification were performed,using a DNA thermal cycler (PTC-100, MJ Research. Inc.) at the thermal condition described in Orui (1996). The amplified products were stored at $-20^{\circ} \mathrm{C}$ until use. The amplified DNA was separated by electrophoresis through 2.0\% Metaphor Agarose (FMC Corp.) gels in $1.0 \mathrm{x}$ TBE buffer. Ten endonucleases (BRL Life Technologies, Inc.) were used to digest the PCR amplified product: AluI, Dde I, Hha I, Hinf I, Taq I, Hae III, Mbo I, Nsp V, Pst I, and Sau96 1. Digestion was conducted in a mixture of $5 \mu \mathrm{l}$ of the amplified product, $1 \mu \mathrm{l}$ of endonuclease and $14 \mu \mathrm{l}$ of buffer for at least $6 \mathrm{hrs}$. at the appropriate temperature. Restriction patterns were analyzed by electrophoresis through $2.0 \%$ Metaphor agarose gel, as described earlier. The gels were stained with ethidium bromide solution $(0.5 \mathrm{mg} / \mathrm{ml})$, and were photographed using Polaroid type 667 films (Polaroid Corp.) on a UV transilluminator.

\section{Systematics}

Pratylenchus japonicus Ryss, 1988 n. stat.

Pratylenchus macrostylus apud Minagawa, 1982 (nec Wu, 1971)

P. macrostylus japonicus Ryss, 1988

\section{Measurements.}

Lectotype (female): $\mathrm{L}=\mathbf{4 2 3} \mu \mathrm{m} ; \mathrm{L}^{\prime}=\mathbf{3 9 9} \mu \mathrm{m} ; \mathrm{a}=\mathbf{2 4}$; $\mathrm{b}=5.3 ; \mathrm{b}^{\prime}=3.3 ; \boldsymbol{c}=\mathbf{1 7 . 0}$ : $\mathrm{c}^{\prime}=\mathbf{2 . 5} ; \mathrm{V}=\mathbf{8 7 . 2} \% ; \mathrm{V}^{\prime}=\mathbf{9 2 . 6} \%$; spear $=19.0 \mu \mathrm{m} ; \mathrm{MB}=61 \% ; \mathrm{Gl}=31.4 \% ; \mathrm{G} 2=$ $5.4 \% ; \mathrm{U}=1.5 ;$ Tail $/ \mathrm{V}-\mathrm{a}=84.4 \%$; E.P. $=17.2 \% ; \mathrm{Ph} .=60.5 \%$.

Paralectotypes (female): Measurements of the paralectotypes from Nishigoshi. Kumamoto (primary syntypes of this species) are given in Minagawa ( 1982). Only the data of newly designated paralectotypes from Nara and Tochigi are given herein in Table 1.

\section{Description.}

Female ( $n=18$, Based on Nara population): Body rather slender $(\mathrm{a}=31.7 \pm$ 2.62) curved ventrally when heat-relaxed. Annuli $0.9 \mu \mathrm{m} \pm 0.10(0.8-1.0)$ wide at midbody. Lip region tapers anteriorly, rounded and elevated, $3.1 \mu \mathrm{m} \pm 0.18$ (2.8-3.3) high. $7.7 \mathrm{~mm} \pm 0.32(7.2-8.2)$ wide, continuous to body contour. Labial framework moderately developed, laterally extending into body at 1 to 2 annule; vestibule extension well developed, cask-shaped. Lip with 3 shallow annuli on both sides (Fig. 1 B-D). which often indiscernible by light microscope but distinct in SEM image (Fig. 3 B). In en face view of 1st lip annule (Fig. 3 A), oral aperture oval and widened, with 6 pore-like inner sensilla at margins, median sensilla indiscernible (Fig. 3 E); amphid apertures slitlike and oblique; median segment fused to lateral segment (Group 1 sensu Corbett and Clark, 1983). Cephalids not seen. Spear $19.8 \mu \mathrm{m} \pm 0.70$ (18.3-21.3) long, 2.6 times $\pm 0.13(2.3-2.8)$ as long as head diameter. Spear knobs massive. $3.7 \mu \mathrm{m} \pm 0.33$ 

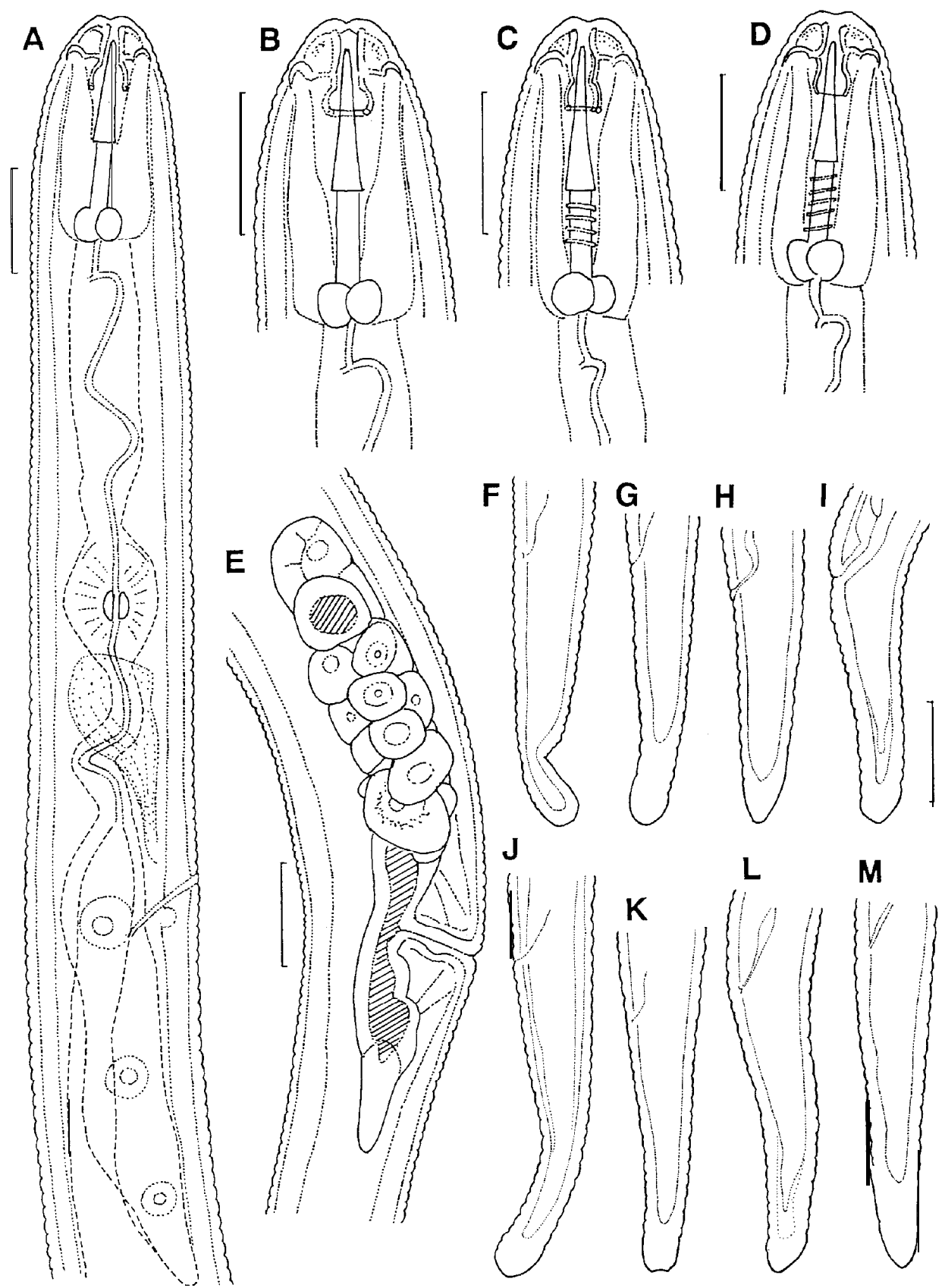

Fig. 1. Pratylenchus japonicus n. stat. - Female. A, oesophageal region; B-D, heads; E, vulval region showing empty spermatheca and anteriorly inclined vagina; F-M, variation of tails. Scale bars $=10 \mu \mathrm{m}$. 

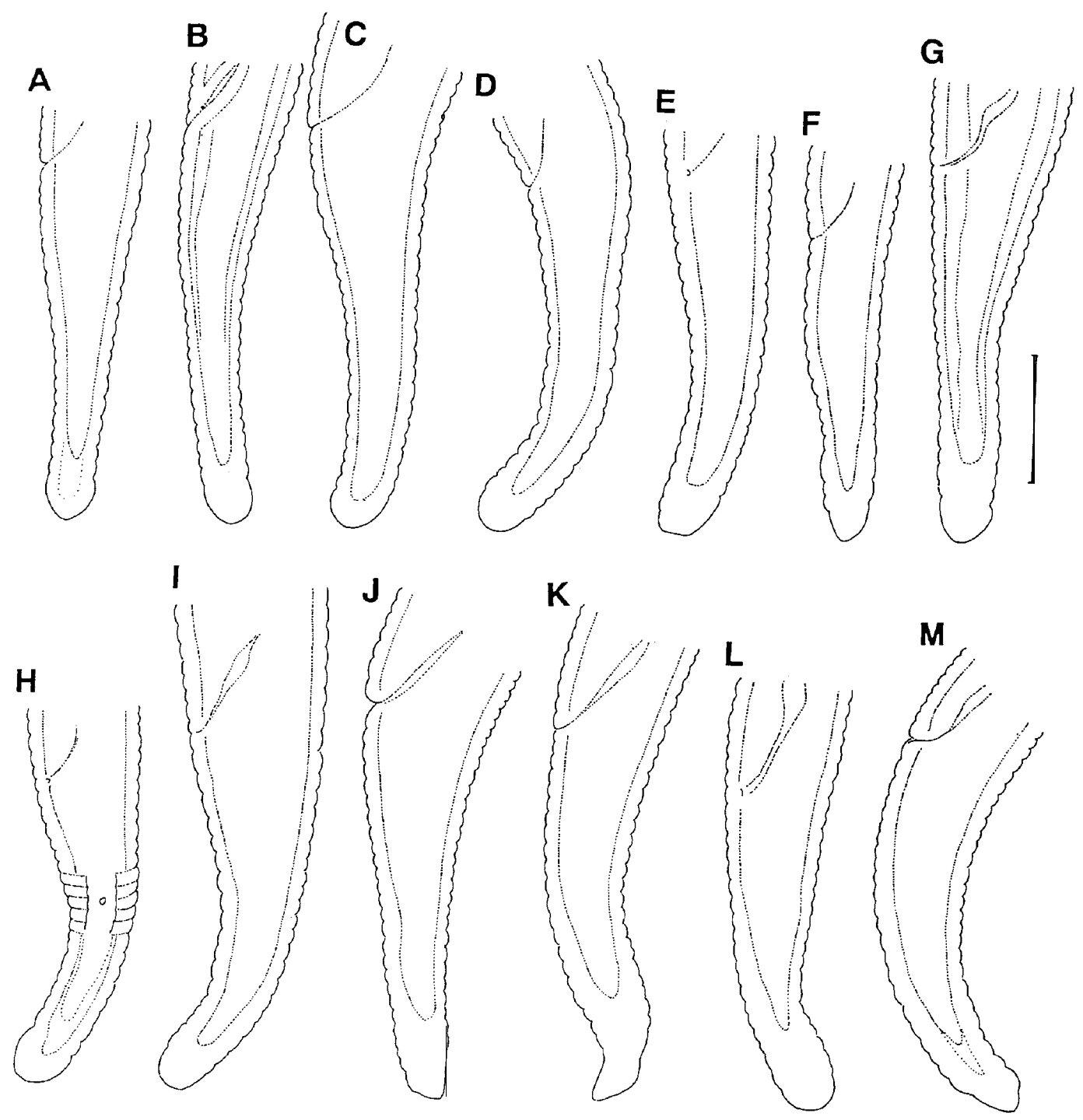

Fig. 2. Morphological variation in tails of Pratylenchus japonicus n. stat. Scale bar = $10 \mu \mathrm{m}$.

(3.3-4.6) high, $4.7 \mu \mathrm{m} \pm 0.34$ (4.3-5.6) across; $1.3 \pm 0.14(0.9-1.5)$ in width / height ratio; shape rather constant, mostly flattened anteriorly or rounded, never indent or sloping posteriorly. DGO $3.3 \mu \mathrm{m} \pm 0.34$ (2.9-3.9) from spear knob base. Metacorpus oval, occupying about a half of the corresponding body diameter; valve conspicuous. 60 $\mu \mathrm{m} \pm 4.3$ (5 1-66) from anterior body end, or $63 \% \pm 11.6$ (42-74) of oesophagus length. Oesophageal basal lobe (Fig. 1 A) extending $132 \mu \mathrm{m} \pm 12.3$ (108-156) from anterior body end, ventrally overlapping intestine $46.3 \mu \mathrm{m} \pm 11.1(29.5-66.8)$ or a distance of 
2.8 times \pm 0.65 (1.6-3.8) the corresponding body diameter. Oesophageal nuclei usually line up (Fig. 1 A). Excretory pore $83 \mu \mathrm{m} \pm 7.3$ (65-92) from anterior body end, $95.6 \%$ $\pm 14.8(62-108)$ of oesophageal length, and $74 \pm 2.6(71-77)(n=4)$ body annuli from anterior body end; annuli between anterior body end and excretory pore $1.1 \mu \mathrm{m}$ in average width. Hemizonid lenticular, 2 to 3 annuli long, level with or immediately anterior to excretory pore.

Gonad outstretched, $126 \mu \mathrm{m} \pm 22.3(87-162)(n=17)$ long; ovary with oocytes generally in a row (rarely partially doubled); spermatheca indistinct, empty, when observed rounded, at $44 \mu \mathrm{m}(n=1)$ from vulva, $9.2(n=1)$ long, $7.9 \mu \mathrm{m}(n=1)$ wide, $1.2(n=1)$ in length/width ratios (Fig. 1 E). Uterus with tricolumella of 15 cells. Postuterine branch undifferentiated, about as long as vulval body diameter $(\mathrm{U}=0.9 \pm 0.24)$ (Fig. 1 E). Vagina narrow walled, anteriorly inclined to body axis, $8.8 \mu \mathrm{m} \pm 1.37$ (6.6$10.0)(n=5)$ long, or $56 \% \pm 6.6(48-63)$ of vaginal body diameter.

Tail $30 \mu \mathrm{m} \pm 2.9$ (24-34) long, with 22 (19-26) annuli, distinctly conoid; apices rounded; terminal cuticular portion moderately broad and much elongate, 3.2 times \pm $0.35(2.6-3.8)$ as long as anal body width $(n=25)$; posterior half distinctly slenderer than anterior half due to rather extensive tapering from anus to middle level; termini with some variation in shape (Fig. 1 F-M; Fig. 2): mostly rounded (52 \%: Fig. 1 G, J; Fig. 2 A-D), often bluntly pointed (33 \%: Fig $1 \mathrm{H}$; Fig. $2 \mathrm{~F}$ ), rarely flattened or concave $(9 \%$ : Fig. 1 K; Fig. 2 E, J), and very rarely clavate (Fig. 1 F); terminus smooth, without evident annuli around. Tail terminal cuticle rather thick, $5.5 \mu \mathrm{m} \pm 1.47$ (2.9-9.2) thick: phasmids pore-like at anterior half of tail, centered in lateral fields (Fig. $2 \mathrm{H}$; Fig. $3 \mathrm{~T}$ ), $11.0 \mu \mathrm{m} \pm$ $1.09(9.2-12.4)(n=8)$ behind anus or $62.9 \% \pm 2.91(59.5-68.8)(n=8)$ from tail tip.

Lateral fields $5.8 \mu \mathrm{m} \pm 0.19(5.6-5.9)(n=3)$ wide, i.e. $34.8 \% \pm 3.80(31.0-38.6)$ of the widest body diameter, consist of 3 equally spaced bands separated by 2 narrow but deep inner grooves (Fig. 3 F); almost plain in mid-body region (Fig. 3 F); and areolated at tail region (Fig. 3 I). Lateral fields never extend tail tip; inner band fused to single groove shortly before phasmid (Fig. 3 I).

The amplified product of ITS regions in rDNA is a single fragment of about $0.8 \mathrm{~kb}$ (Fig. 4, lane 1). The restriction patterns and the DNA fragment sizes obtained after digestion of ten endonucleases are given in Fig. 4 (lanes 2-1 1) and Table 2.

Males: Unknown.

Type material and locality.

Lectotype: 1 female, Nishigoshi, Kumamoto Pref., collected from Quercus acutissima, 16. iv. 1979, leg. N. Minagawa. Specimen is deposited at the Herbarium and Insect Museum of the National Institute of Agro-Environmental Sciences, Tsukuba City, Ibaraki, Japan (NIAES).

Paralectotypes: 49 females, Nishigoshi, Kumamoto Pref., collected from Quercus acutissima Carruth., Q. dentata Thumb. and Q. serrata Murray, 16. iv. 1979, leg. N. Minagawa; 25 females, Mt. Nijo-san, Taima Town, Kitakatsuragi-gun, Nara Pref., collected from unidentified tree, iii. 1987, leg. T. Mizukubo; 3 females, Kokubunji Town, Shimotsuga-gun, Tochigi Pref., collected from cherry tree, 1996, leg. Y. Orui. Specimens are deposited at the NIAES and the Laboratory of Plant Nematology, Kyushu National Agricultural Experiment Station (KNAES). 
Table 1. Measurement of Pratylenchus japonicus n. stat. from two locations in Japan. (females; data in $\mu \mathrm{m}$ ).

\begin{tabular}{|c|c|c|c|c|c|c|c|c|c|c|c|c|c|c|}
\hline \multirow[b]{2}{*}{ Characters } & \multicolumn{7}{|c|}{$\begin{array}{c}\text { Taima, Nara } \\
\text { HW/TAF/GE } \\
\text { H) }\end{array}$} & \multicolumn{7}{|c|}{$\begin{array}{c}\text { Kokubunji, Tochigi } \\
\text { HW/TAF/LP }\end{array}$} \\
\hline & $\min$ & $-\max$ & mean & \pm S.D. & & C.V. & $\mathrm{n}$ & $\min$ & $-\max$ & mean & $\mathrm{n} \pm$ S.D. & & C.V. & $\mathrm{n}$ \\
\hline $\mathrm{L}$ & 404 & -616 & ( 521 & \pm 58.3 & ) & 11.2 & 18 & 454 & -553 & ( 520 & $0 \pm 46.3$ & ) & 8.9 & 3 \\
\hline $\mathrm{L}$ & 375 & -590 & ( 491 & \pm 58.7 & ) & 12.0 & 18 & 424 & -526 & ( 491 & $1 \pm 45.9$ & ) & 9.3 & 3 \\
\hline $\mathrm{a}$ & 24.7 & -36.0 & ( 31.7 & \pm 2.62 & ) & 8.3 & 18 & 28.2 & -32.4 & ( 29.8 & $8 \pm 1.86$ & ) & 6.2 & 3 \\
\hline $\mathrm{b}$ & 5.6 & -7.1 & ( 6.4 & \pm 0.56 & ) & 8.8 & 12 & 5.5 & -6.6 & ( 6.1 & \pm 0.44 & ) & 7.3 & 3 \\
\hline b & 3.1 & -5.1 & $(4.0$ & \pm 0.49 & ) & 12.2 & 16 & 3.5 & -4.3 & ( $\quad 3.9$ & $9 \pm 0.33$ & ) & 8.4 & 3 \\
\hline c & 13.3 & -23.5 & ( 17.6 & \pm 2.83 & ) & 16.1 & 18 & 16.5 & -20.6 & ( 18.5 & $5 \pm 1.67$ & ) & 9.0 & 3 \\
\hline$c^{\prime}$ & 2.6 & -3.8 & ( 3.2 & \pm 0.35 & ) & 10.7 & 18 & 2.4 & -2.9 & ( $\quad 2.7$ & $7 \pm 0.20$ & ) & 7.5 & 3 \\
\hline v (\%) & 84.3 & - 88.2 & ( 86.2 & \pm 1.21 & ) & 1.4 & 18 & 85.7 & -87.7 & ( 86.8 & \pm 0.82 & ) & 0.9 & 3 \\
\hline$V(\%)$ & 90.3 & -93.1 & ( 91.5 & \pm 0.77 & ) & 0.8 & 18 & 91.3 & - 92.2 & ( 91.8 & $8 \pm 0.41$ & ) & 0.4 & 3 \\
\hline VL & 347 & -538 & ( 449 & \pm 54.3 & ) & 12.1 & 18 & 389 & -485 & ( 452 & \pm 44.0 & ) & 9.7 & 3 \\
\hline $\mathrm{Gl}(\%)$ & 16.9 & -31.1 & ( 24.2 & \pm 3.98 & ) & 16.5 & 17 & 17.4 & -23.2 & ( 21.2 & \pm 2.64 & ) & 12.5 & 3 \\
\hline G2 (\%) & 1.4 & -4.4 & ( 2.7 & \pm 0.80 & ) & 30.1 & 15 & 2.2 & -4.0 & ( $\quad 3.2$ & \pm 0.73 & ) & 22.8 & 3 \\
\hline Spear & 18.3 & -21.3 & ( 19.8 & \pm 0.70 & ) & 3.5 & 20 & 18.3 & -20.8 & ( 19.3 & \pm 0.70 & ) & 3.6 & 3 \\
\hline Oesophagus & 70 & -156 & ( 97 & \pm 26.8 & ) & 27.6 & 16 & 82 & -90 & ( 85 & \pm 3.1 & ) & 3.7 & 3 \\
\hline MB (\% & 41.6 & -74.0 & ( 63.2 & \pm 11.6 & ) & 18.3 & 16 & 65.7 & - 67.2 & ( 66.3 & \pm 0.67 & ) & 1.0 & 3 \\
\hline Excr & 65 & -92 & ( 83 & \pm 7.33 & ) & 8.8 & 14 & 71 & -97 & ( 83 & \pm 6.00 & ) & 7.2 & 3 \\
\hline Excr. & 14.1 & -18.3 & ( 16.0 & \pm 1.21 & ) & 7.6 & 14 & 16.1 & - 17.4 & ( 16.7 & \pm 0.55 & ) & 3.3 & 3 \\
\hline $\mathrm{V}-\mathrm{a}$ & 28 & -52 & ( 41 & \pm 6.0 & ) & 14.4 & 18 & 37 & -41 & ( 40 & \pm 1.9 & ) & 4.6 & 3 \\
\hline Tail & 23.6 & -34.0 & ( 30.0 & \pm 2.87 & ) & 9.6 & 18 & 26.8 & -30.1 & ( 28.1 & \pm 1.41 & ) & 5.0 & 3 \\
\hline Tail/V-a & 50.6 & -104.7 & ( 73.7 & \pm 12.9 & ) & 17.6 & 18 & 65.1 & - 73.7 & ( 70.6 & \pm 3.91 & ) & 5.5 & 3 \\
\hline Annule width & 0.8 & -1.0 & ( 0.9 & \pm 0.10 & ) & 10.4 & 6 & 0.9 & -1.3 & ( 1.0 & \pm 0.19 & ) & 19.0 & 3 \\
\hline PUB & 8.5 & - 19.6 & ( 13.4 & \pm 2.99 & ) & 22.2 & 15 & 12.4 & - 18.3 & ( 16.1 & \pm 2.64 & ) & 16.4 & 3 \\
\hline $\mathrm{U}$ & 0.5 & -1.5 & ( 0.9 & \pm 0.24 & ) & 26.2 & 15 & 0.8 & -1.3 & ( 1.1 & \pm 0.25 & ) & 22.7 & 3 \\
\hline Spear/Head width & 2.3 & -2.8 & ( 2.6 & \pm 0.13 & ) & 5.2 & 19 & 2.3 & -2.5 & ( 2.4 & \pm 0.09 & ) & 3.8 & 3 \\
\hline m (\%) & 50.0 & -56.7 & ( 52.9 & \pm 1.67 & ) & 3.2 & 20 & 48.4 & -52.2 & $(50.2$ & \pm 1.49 & ) & 3.0 & 3 \\
\hline SPM length/width & & - & ( 1.2 & & ) & & 1 & & & ( & \pm & ) & & \\
\hline LFW/body width(\%) & 31.0 & -38.6 & ( 34.8 & \pm 3.8 & ) & 10.9 & 3 & 34.6 & -34.6 & ( 34.6 & & ) & 0.0 & 3 \\
\hline REX & 71 & -77 & $(74.0$ & \pm 2.58 & ) & 3.5 & 4 & 70 & -75 & ( 72.3 & \pm 2.05 & ) & 2.8 & 3 \\
\hline Tail annuli & 19 & -26 & ( 21.9 & \pm 2.20 & ) & 10.1 & 9 & 22 & -26 & ( 24.3 & \pm 1.70 & ) & 7.0 & 3 \\
\hline Phasmid & 9.2 & -12.4 & ( 11.0 & \pm 1.09 & ) & 10.0 & 8 & 9.8 & -15.1 & ( 12.4 & \pm 2.62 & ) & 21.1 & 3 \\
\hline $\mathrm{Ph} .(\%)$ & 59.5 & -68.8 & ( 62.9 & \pm 2.91 & ) & 4.6 & 8 & 50.0 & -63.4 & ( 56.7 & \pm 6.71 & ) & 11.8 & 3 \\
\hline Knob width & 0.9 & -1.5 & ( 1.3 & \pm 0.14 & ) & 10.9 & 20 & 1.2 & -1.3 & ( 1.2 & \pm 0.03 & ) & 2.5 & 3 \\
\hline Oes. overlap & 29.5 & -66.8 & ( 46.3 & \pm 11.1 & ) & 23.9 & 12 & 45.8 & -47.8 & ( 46.5 & \pm 0.93 & ) & 2.0 & 3 \\
\hline Head height & 2.8 & -3.3 & ( 3.1 & \pm 0.18 & ) & 5.9 & 17 & 2.7 & -3.3 & ( 2.9 & \pm 0.21 & ) & 7.2 & 3 \\
\hline Head width & 7.2 & -8.2 & ( 7.7 & \pm 0.32 & ) & 4.2 & 20 & 7.5 & -8.8 & 8.1 & \pm 0.56 & ) & 6.9 & 3 \\
\hline D.G.O. & 2.9 & -3.9 & ( 3.3 & \pm 0.34 & ) & 10.3 & 14 & 3.3 & -3.6 & 3.4 & \pm 0.16 & ) & 4.7 & 3 \\
\hline Knob height & 3.3 & -4.6 & ( 3.7 & \pm 0.33 & ) & 9.0 & 20 & 2.9 & -3.6 & 3.3 & \pm 0.23 & ) & 7.0 & 3 \\
\hline Knob width & 4.3 & -5.6 & ( 4.7 & \pm 0.34 & ) & 7.3 & 20 & 3.7 & -4.6 & 4.1 & \pm 0.39 & ) & 9.5 & 3 \\
\hline Oes. (lobe) & 108 & -156 & ( 132 & \pm 12.3 & ) & 9.4 & 16 & 130 & -136 & ( 132 & \pm 2.6 & ) & 2.0 & 3 \\
\hline SPM length & 9.2 & -9.2 & ( 9.2 & & ) & & & & & ( & \pm & ) & & \\
\hline SPM v & 7.9 & -7.9 & ( 7.9 & & ) & & & & & ( & \pm & ) & & \\
\hline Max body w. & 13.7 & $=20.9$ & ( 16.5 & \pm 1.85 & ) & 11.3 & 18 & 15.7 & - 19.6 & ( 17.5 & \pm 1.63 & ) & 9.3 & 3 \\
\hline Vaginal body w. & 12.4 & - 17.7 & ( 14.6 & \pm 1.39 & ) & 9.5 & 18 & 13.7 & - 16.4 & ( 14.8 & \pm 1.11 & ) & 7.5 & 3 \\
\hline al body w. & 7.9 & -11.1 & ( 9.3 ) & \pm 0.82 & ) & 8.8 & 18 & 9.8 & - 11.1 & ( 10.5 & \pm 0.53 & ) & 5.0 & 3 \\
\hline $\mathrm{SPM} / \mathrm{V}-\mathrm{a}(\%)$ & 112 & -112 & $(112$ & & ) & & & 106 & -111 & ( 108 & \pm 2.1 & ) & 1.9 & 3 \\
\hline Dverlap./Body w. & 1.6 & -3.8 & $(2.8=$ & \pm 0.65 & ) & 23.5 & 12 & 2.3 & -3.0 & 2.7 & \pm 0.29 & ) & 10.7 & 3 \\
\hline 11 cuticle & 2.9 & - 9.2 & ( 5.5 ) & \pm 1.47 & ) & 26.7 & 15 & 5.2 & -6.5 & 6.0 & \pm 0.56 & ) & 9.3 & 3 \\
\hline UB/V-a (\%) & 16.5 & -58.1 & $(33.6$ & \pm 10.9 & & 18.8 & 15 & & & ( & \pm & & & \\
\hline
\end{tabular}

Abbreviations: $\mathrm{V}-\mathrm{a}=$ vulva-anus distance; $\mathrm{PUB}=$ post vulvar uterine branch; SPM=spermatheca.

a) Killed in hot water $(60$ "C), fixed in TAF, and processed by glycerol ethanol method.

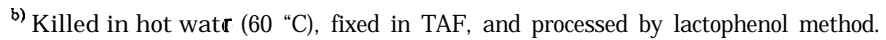


Table 2. Fragment sizes (bp a) ) resulting from digestion of an ITS region of Pratylenchus japonicus n. stat. with 10 endonuleases.

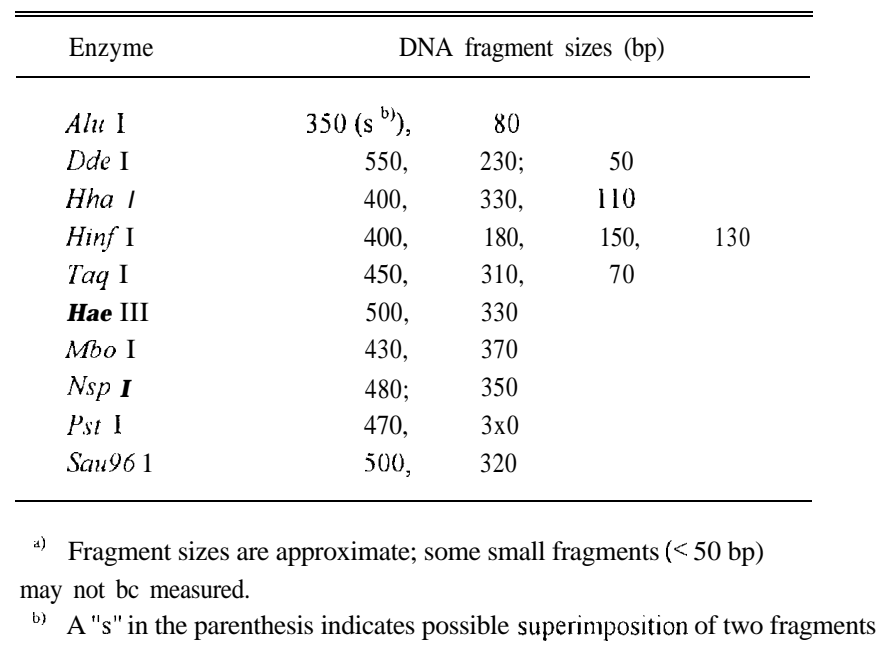

Diagnosis and relationships.

Pratylenchus japonicus $\mathrm{n}$. stat. is characterized by the first lip annule with distinctly convex anterior margin, long and stout spear $(18-21 \mu \mathrm{m})$, posterior vulva $(\mathrm{V}=84-88 \%)$, empty spermatheca, shorter post-vulva1 uterine branch (PUB $=9-20 \mu \mathrm{m} ; \mathrm{G} 2=$ about $3 \%$ ), and slender tail with smooth tail terminus. This species resembles P. macrostylus Wu. 1960 and P. brachyurus Godfrey, 1929, by having elongate spear and posterior vulva. Pratylenchus brachyurus differs from $P$. japonicus by having flattened first lip annule with angular lateral edges and stout tail terminus. Pratylenchus japonicus is primary distinguished from $P$. macrostylus by having shorter spear (18-21 $\mu \mathrm{m}$ vs. 2 1-28 $\mu \mathrm{m})$. Although difficult to ascertain, 3-annule lip of $P$. japonicus differ from 2-annule lip of $P$. macrostylus. There are further considerable differences of taxonomic importance between the two species, which are mentioned in the discussion.

\section{Discussion}

Hartman and Eisenback (1991) and Ryss (1988) distinguished the Japanese $P$. macrostylus from North American populations because of the differences in spear length. However, stable in many Pratylenchus species it may be, the spear length is one of the quantitative characters. It is not determined if the character in this species will be subjected to the variation due to environmental or genetic factors.

Comparing with the full redescription and the detailed SEM images of the North American P. macrostylus provided by Hartman and Eisenback (1991), it was found that further taxonomically critical differences laid between the two geographic populations as follows: i) $P$. macrostylus has the vestibule extension of cephalic frame work that is 
simply widening posteriad, but the structure of $\mathbf{P}$. japonicus is steadily cask-shaped, i.e. it is widened at middle and constricted at the posterior end; ii) en face pattern of $\mathbf{P}$. macrostylus by SEM showed the differentiated segment that can be classified into Group 2 , but $\mathbf{P}$. japonicus has undivided face pattern (Group 1); iii) en face image showed normal 3 distinct inner sensilla at the margins of oral aperture (total 6), but since $\mathbf{P}$. juponicus has much reduced median sensilla it appeared to have only two inner sensilla (total 4: Fig. 3 E). We consider that these differences in the above-mentioned
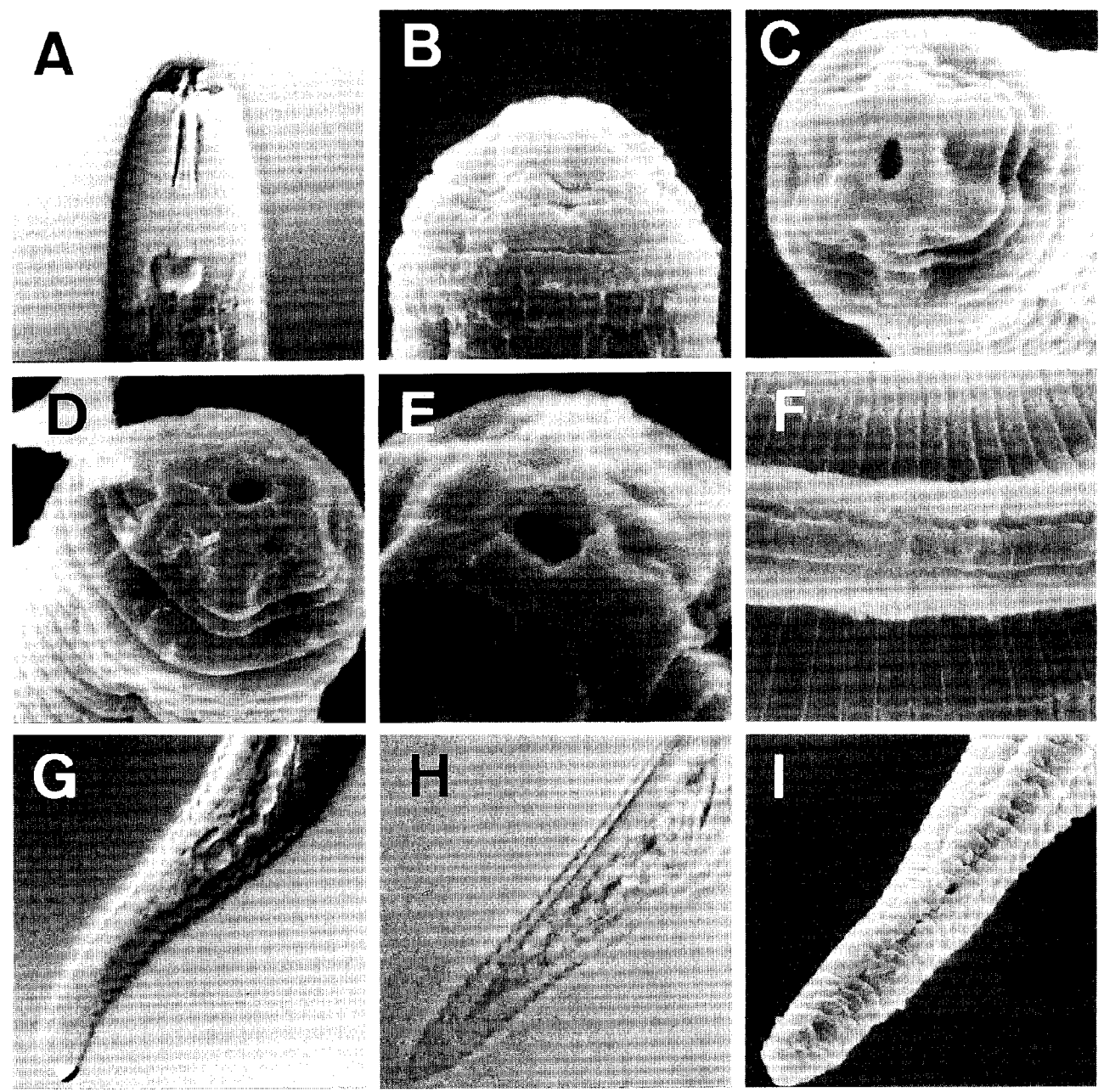

Fig. 3. Light microscopic (A, G, H) and scanning electron microscopic (B-F. I) photographs of Pratylenchus juponicus n. stat. from Japan. A, anterior body end (lateral view); B, lip region showing 3-lip annule (lateral view); C \& D, lip region showing plane face (en face view); E, first lip annule showing much reduced median inner sensilla (en face view); F, lateral fields showing deep inner incisures; $\mathrm{G}$ - I, tails (lateral view). 


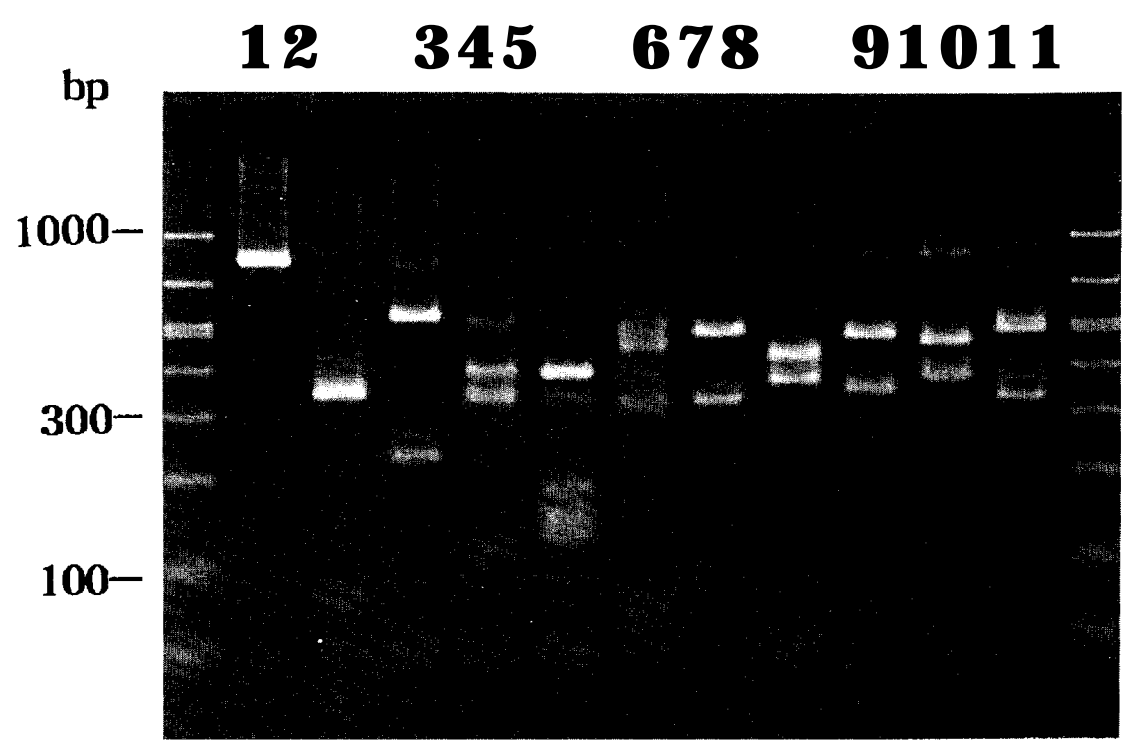

Fig. 41. An amplified internal transcribed spacer region of the rDNA from a single female of Pratylenchus japonicus n. stat. and its restriction patterns obtained after 10 endonuclease digestion. Ethidium bromide stained $2.0 \%$ Metaphor agarose gel. Sides, BioMarker (Bio Ventures, Inc.); lane 1, amplification product without digestion; lane 2, Alu I; lane 3, Dde I; lane 4, H ha I; lane 5, Hinf I; lane 6, TaqI: lane 7, Hae III; lane 8, Mbo I; lane 9, Nsp V; lane 10, Pst I; lane 11, Sau96I.

characteristics between the Japanese and North American populations are regarded as specific rather than subspecific level. A specific epithet for the Japanese populations should succeed a previously designated subspecific epithet, the "japonicus"(Ryss, 1988). Then, the Japanese populations are elevated to the specific rank as Pratylenchus japonicus Ryss, $1988 \mathrm{n}$. stat. in this paper. A lectotype and a large part of lectoparatypes for the new species are chosen from the syntypes of P. macrostylus japonicus Ryss. 1989 that had comprised specimens measured and described by Minagawa ( 1982). Specimens form Nara and Tochigi are also designated to be paralectotypes, because the morphological and molecular characterization of this new species are perfomed on these specimens.

The eukaryotic rDNA repeat consists of three genes (18S,28S, and 5.8S), internal and external transcribed spacers, and an external nontranscribed spacer region. The sequences of rDNA genes are highly conserved. However, because there is less conservation within the ITS regions, the PCR-RFLP pattern of the ITS regions in rDNA is a useful tool for the taxonomy of eukaryotic organism including nematodes (Hyman and Powers, 1991; White et al., 1990). It was shown that the sizes of PCR products were variable between species belonging to the genus Pratylenchus, i.e.; ca. $\mathbf{7 . 5 0}$ bp in $\mathbf{P}$. penetrans and P. vulnus, or ca. $1100 \mathrm{bp}$ in P. coffeae and closely allied undescribed species (Orui, 1996). Orui and Mizukubo (not shown here) found that the PCR amplified products were clearly distinguishable two fragments in the species of P. brachyurus, $\mathbf{P}$. 
neglectus, $P$. zeae, and $P$. crenatus. Determined products sizes were identically 700 and $750 \mathrm{bp}$ for $P$. brachyurus, $P$. neglectus, and $P$. zeae, or 800 and $900 \mathrm{bp}$ for P. crenatus. Therefore, the single amplified product of $P$. japonicus $n$. stat. of ca. $800 \mathrm{bp}$ was unique among the species. The DNA fragment sizes obtained after 10 endonucleases digestion shown in this study were also unique among the Pratylenchus species. Because the PCRRFLP fragment sizes are species-specific in the morphologically recognized Pratylenchus species (Orui, 1996), these molecular data can be useful taxonomic characters for the specific level. Present PCR-RFLP data for P. japonicus n. stat. will be helpful to distinguish this species from the North American P. macrostylus, when the PCR-RFLP study of the latter is performed.

\section{References}

Courtney, W. D., D. Polley and V. L. Miller, 195.5. TAF, an improved fixative in nematode technique. PI. Dis. Reptr., 39: 570-57 1.

Corbett, D. C. M. and S. A. Clark, 1983. Surface features in the taxonomy of Pratylenchus species. Revue Nematol., 6: 85-98.

Ferris, V. R., J. M. Ferris, and J. Faghihi, 1993. Variation in spacer ribosomal DNA in some cyst-forming species of plant parasitic nematodes. Fundam.appl.Nematol., 16: 177-184.

Gotoh, A. 1974. Geographic distribution of Pratylenchus spp. (Nematoda : Tylenchida) in Japan. Bull. Kyushu agric. Expt.Sta., 17: 139-224. (In Japanese with English summary)

Gotoh, A., and Y. Ohshima, 1963. Pratylenchus species and their geographic distribution in Japan (Nematoda: Tylenchida). Jpn. J. appl. Entomol. Zool., 7: 187-199. (In Japanese with German summary)

Hartman, K. M. and J. D. Eisenback, 1991. Amended description of Pratylenchus macrostylus Wu, 1971 with SEM observations. J. Nematol., 23: 104-109.

Hyman, B. C. and T. 0. Powers, 1991. Integration of molecular data with systematics of plant parasitic nematodes. Ann. Rev. Phytopathol. 29: 89- 107.

Loof, P. A. A., 1991. The family Pratylenchidae Thorne, 1949. In W. R. Nickle (ed.) "Manual of Agricultural Nematology" pp. 363-421, Marcel Dekker, Inc., New York.

Minagawa, N., 1982. Description of Pratylenchus gibbicaudatus n. sp. and $P$. macrostylus Wu, 1971 (Tylenchida: Pratylenchidae) from Kyushu. Appl. Entomol. Zool., 17: 418-423.

Orui, Y., 1996. Discrimination of the main Pratylenchus species (Nematoda: Pratylenchidae) in Japan by PCR-RFLP analysis. Appl. Entomol. Zool., 31: 505514.

Ryss, A. Yu., 1988. Kornevye paraziticheskie nematody semeistva Pratylenchidae (Tylenchida) mirovoi fauny. [World Fauna of the Root Parasitic Nematodes of the Family Pratylenchidae (Tylenchida).] Leningrad. USSR. 367 pp. (In Russian)

Seinhorst, J. W., 1959. A rapid method for the transfer of nematodes from fixative to anhydrous glycerin. Nematologica, 4: 67-69.

White, T. J., T. Bruns, S. Lee, and J. Taylor, 1990. Amplification and direct sequencing 
of fungal ribosomal RNA genes for phylogenies. In M. A. Innis, D. H. Gelfand, J. J. Sninsky, and T. J. White (eds.). "PCR Protocols". pp. 315322, Academic Press, San Diego, CA.

Zijlstra, C., A. E. Lever, B. J. Uenk and C. H. Van Silfhout, 1995. Differences between ITS regions of isolates of root-knot nematodes Meloidogyne hapla and $M$. chitowoodi. Phytopathology, 85: 123 1-1 237. 